\title{
Statyba
}

\section{TEST OF ACCELERATED RELAXATION IN PRESTRESSED REINFORCEMENT UNDER THERMAL CONDITIONS OF FIRE}

\author{
Dr Eng. Z. Bednarek
}

To cite this article: Dr Eng. Z. Bednarek (1996) TEST OF ACCELERATED RELAXATION IN PRESTRESSED REINFORCEMENT UNDER THERMAL CONDITIONS OF FIRE, Statyba, 2:6, 18-22, DOI: $10.1080 / 13921525.1996 .10531639$

To link to this article: https://doi.org/10.1080/13921525.1996.10531639

Published online: 26 Jul 2012.

Submit your article to this journal $₫$

Џ Article views: 42 


\section{TEST OF ACCELERA'TED RELAXATION IN PRESTRESSED REINFORCEMENT UN- DER THERMAL CONDIIIONS OF FIRE}

\section{Z. Bednarek}

\section{Introduction}

The issue of fire resistance of pretensioned prestressed concrete structures is of a complex character. These structures indicate a reduced fire resistance in comparison with the similar reinforced concrete structures. This is caused by a few factors:

- the sections of prestressed structures are smaller,

- high-grade steel is less resistant to high temperatures,

- during a firc an accelerated relaxation of stresses in stecl takes place, causing a drop of pretension force, the considerable strains and cracking.

Within the pretensioned prestressed concrete structures under conditions of fire a reduction of concrete - stecl adhesion takes place additionally, i. e. a reduction of a group of factors enabling to transfer the force of steel pretension to concrete. These disadvantageous phenomena cannot be compensated by a tighter layer of concrete and higher accuracy of performance, increasing the insulating properties of coating.

A drop of pretension force, resulting from an accelerated relaxation of stresses, is one of the basic factors, affecting the performance of prestressed structures during fire and influencing a failure period of these structures.

Under normal conditions the losses concerned are relatively low. At the most common values of the characteristic strength of wires the relaxation amounts to $30 \div 60 \mathrm{MPa}$. In case of application of the treatment aiming to reduce the relaxation losses, depending upon an initial overloading of the wires for a short period of time, the lower one of the given values might be assumed. Even in case of raised temperatures the losses take place with a higher velocity.
Some studies presented the test results, aiming to ascertain the drop of pretension force on the basis of relaxation tests under constant raised temperatures $[1,2]$. Figures $1 \mathrm{a}$ and $1 \mathrm{~b}$ present these test results in diagrams showing that even relatively low temperatures can cause considerable losses of pretension force. These tests do not provide any basis to evaluate the drop of pretension force during a standard fire, since the test conditions differ substantially from those assumed to indicate the fire resistance of the structure.
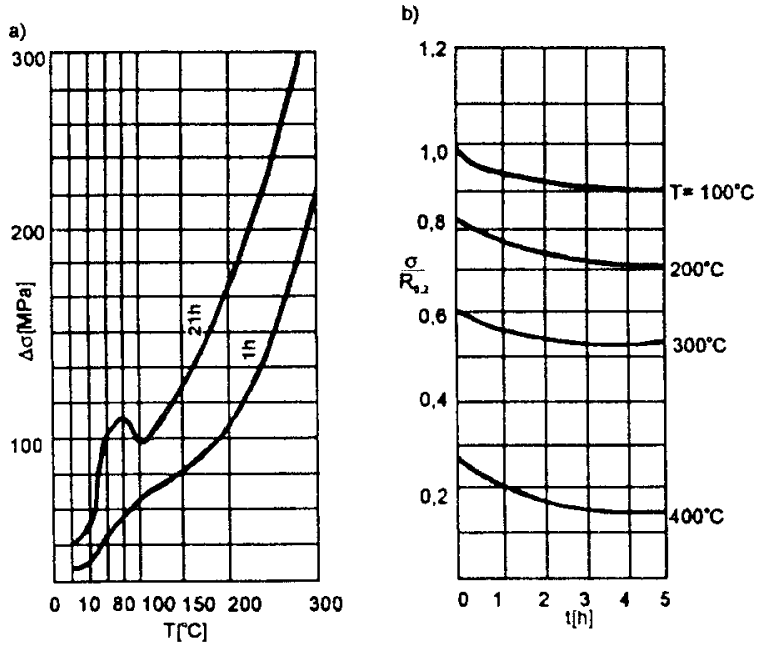

Fig. 1. Diagram of the drop of pretension stresses in the prestressing steel at high temperatures a) according to Claudde b) according to Cahill and Branch

\section{Tests of the pretension force drop in strands re- sulting from temperature increase}

The target of the tests was to define the drop of pretension force under conditions of a standard fire due to the distribution of prestressing strands taking place at various depth in relation to the faces of slabs 
and beams being heated and a few ,temperaturetime" distributions have been selected for testing.

Two lypes of strands (I and II) made of the highcarbon dead stecl strings have been subjected to the tests:

Type I: Strands used for production of pretensioned prestressed concrete floor beams type: FRB, manufactured in Poland on the basis of a license of French company OTEP. They are produced of three strings, $\varnothing 2.5 \mathrm{~mm}\left(f_{z}=13.6 \mathrm{sq} . \mathrm{mm}\right)$.

The characteristic strength of a string amounts 10 $R_{i k}=1963 \mathrm{MPa}$. $A$ minimum destroying force of a strand, indicated on the basis of tests and guaranteed by the manufacturer, amounts to $P_{r}=26.7 \mathrm{kN}\left(R_{s}=1963 \mathrm{MPa}\right)$. Fig. 2a shows the pattern of strings in a strand. A durable pretension stress of the strands (after the losses reduction) amounts to:

$$
\sigma_{v}=0.55 R_{v k}=0.55 \cdot 1963=1079.65 \mathrm{MPa}
$$

б. stress has been assumed as an initial one for the purpose of the relaxation tests of steel under the conditions of fire.
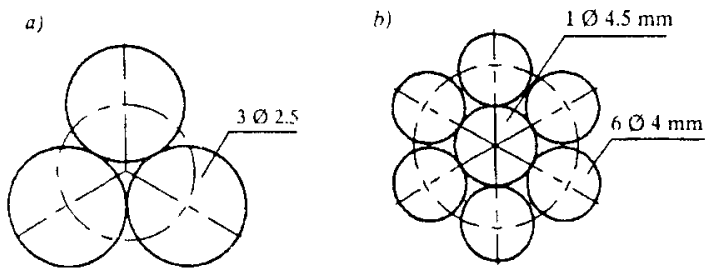

Fig. 2. Distribution of wires in strands
a) type $I$
b) type II

Type II: Strands of Czech production applied in the eightics for manufacturing channel pretensioned prestressed slabs, type SP, produced by the FAEL_BET Works.

The strands have been made of the following strings: $1 \varnothing 4.5+6 \varnothing+\left(f_{z}=91.3\right.$ sq. mm). Fig. $2 \mathrm{~b}$ shows the location of the strings. The characteristic strength of a string amounts to $R_{v k}=$ $1600 \mathrm{MN} / \mathrm{sq}$. m. The minimum force destroying the strand, defined on the basis of the tests, amounts to $P_{r}=140 \mathrm{kN}\left(R_{r s}=1532 \mathrm{MN} / \mathrm{sq}\right.$. $\mathrm{m})$. The durable pretension stress of the strands amounts to:

$$
\sigma_{v}=0.55 R_{r s}=0.55 \cdot 1532=852 \mathrm{Mpa}
$$

$\sigma_{v}$ stress has been assumed as an initial one for the relaxation tests of steel under the conditions of fire.

\section{Information on tests methodology}

The Griford type conical holders were used to fix the samples in the strength machinery.

The following option of the machincry operation was applied for the tests (relaxation test): an automatic maintaining of a constant elongation value with a simultaneous recording of the strand tensile force drop during the test.

The measurement and the control of temperature on the sample surface was carried out by means of two $\mathrm{Ni}-\mathrm{Cr}$ - Ni thermocouples and a temperature controller and recorder.

The temperature on the surface of the samples (strands) increased according to the "temperaturetime" curves shown in Fig. 4 and 5.

The "temperature-time" distribution patterns have been applied for the tests. These patterns were obtained as a result of application of a TEMP computer program, having been elaborated by the author, aiming to numerical defining of the single-dimension ficld of temperatures in a reinforced concrete item.

The test has been carried out until a full drop of the initial pretension force of the strands. Fig. 3 shows a sample with fixed thermocouples.

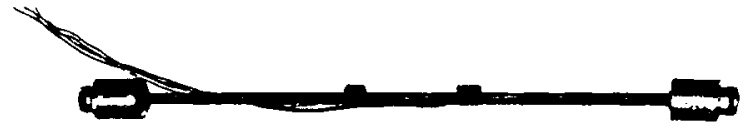

Fig. 3. View of a sample with thermocouples

\section{Test results}

Due to an approximation of the test results a formula has been elaborated, defining a percentage value of pretension force, remaining after the losses from the accelerated relaxation:

$$
P_{s}=A \cdot t^{2}+B t+C
$$

where:

$P_{s}$ - remaining pretension force, ${ }_{c} c$
$t$ - time, min. 


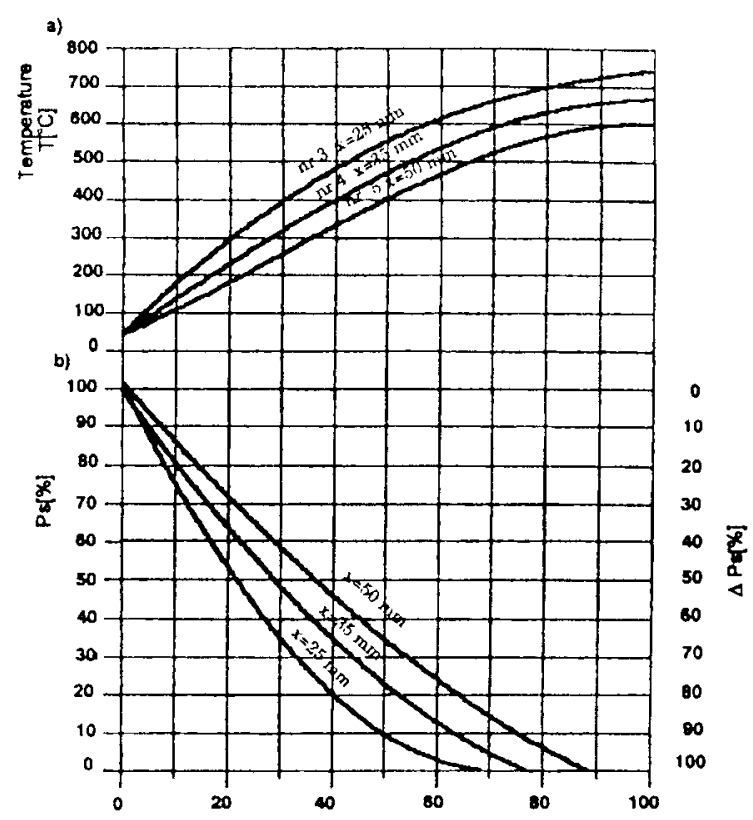

Fig. 4. Drop of pretension force in the type I strands under the thermal conditions defined by the distributions No. 3, No. 4, No. 5

a) temperature distributions

b) diagrams of drop of pretension force

$A, B$ - coefficients depending upon the assumed temperature distribution for the tested grade of restressing stecl

$C=100 \%$ - the assumed percentage value of pretension force prior to the losses from the accelerated relaxation.

The percentage drop of pretension force $\Delta P_{s}$ amounts to:

$$
A P_{s}=A t^{2}+B t
$$

Table 1 presents the values of $A$ and $B$ coefficients for the two tested strands of prestressing steel.

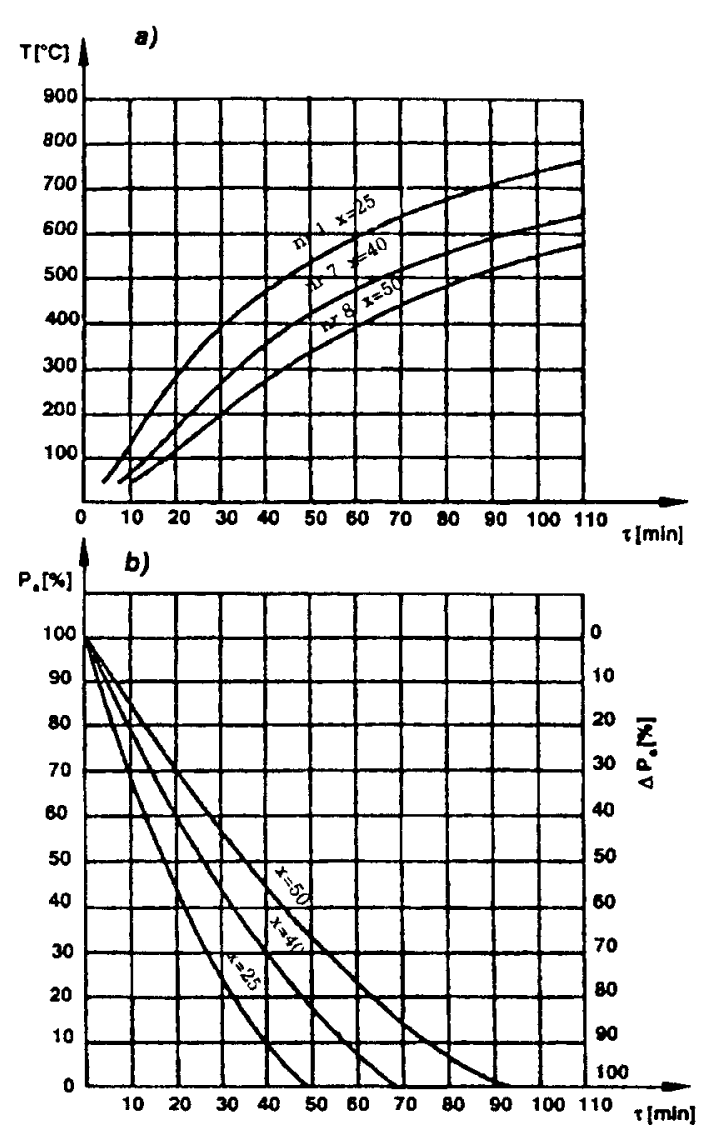

Fig. 5. Drop of pretension force in the type II strands under the thermal conditions defined by the distributions No. 4 , No. 7 , No. 8

a) temperature distributions

b) drop diagrams

\section{Table 1}

\begin{tabular}{|c|c|c|c|c|c|}
\hline Steel grade & $\begin{array}{c}\text { Temperature } \\
\text { distribution }\end{array}$ & $\begin{array}{c}\text { Number of } \\
\text { samples in lots }\end{array}$ & A & B & $\begin{array}{c}\text { Correlation } \\
\text { coeflicient }\end{array}$ \\
\hline \hline \multirow{2}{*}{$\mathbf{1}$} & $\mathbf{2}$ & $\mathbf{3}$ & $\mathbf{4}$ & $\mathbf{5}$ & $\mathbf{6}$ \\
\hline \multirow{3}{*}{$\mathbf{1}$} & No. 3 $(\mathrm{x}=25 \mathrm{~mm})$ & 20 & 0,01898 & $-2,777$ & 0,99 \\
\cline { 2 - 6 } & No. $4(\mathrm{x}=35 \mathrm{~mm})$ & 20 & 0,00897 & $-1,986$ & 0,95 \\
\cline { 2 - 6 } & No. $5(\mathrm{x}=50 \mathrm{~mm})$ & 20 & 0,00494 & $-1,585$ & 0,91 \\
\hline \multirow{3}{*}{ II } & No. 4 $(\mathrm{x}=25 \mathrm{~mm})$ & 20 & 0,02620 & $-3,320$ & 0,97 \\
\cline { 2 - 6 } & No. $7(\mathrm{x}=40 \mathrm{~mm})$ & 20 & 0,01010 & $-2,160$ & 0,98 \\
\cline { 2 - 6 } & No. $8(\mathrm{x}=50 \mathrm{~mm})$ & 20 & 0,00590 & $-1,620$ & 0,98 \\
\hline
\end{tabular}




\section{Verification of test results}

Fire resistance of the IARB floor slabs has been experimentally evaluated as 30 minutes. $A$ calculation of pretension force drop in the strands of the beams in the IRRB 312 floor slabs after 30 minutes, evaluated as the fire resistance of these floor slabs, amounts to:

- 2 strands at the distance of $25 \mathrm{~mm}$ from the floor slab bottom surface - $65 \%$,

- 1 strand, depth : $50 \mathrm{~mm}-40 \%$ of drop of pretension force.

The drop of the pretension force for the FRIB 312 beam under the conditions close to the standard fire after 30 minutes will achieve $57 \%$. According to the calculations, in case of $60 \%$ drop, dangerous deflections appear and later a failure takes place.

An increase of deflections in pretensioned prestressed concrete slabs under fire conditions is taking place gradually which is connected with a gradual drop of pretension force in the strands. The se deflections are visible which is advantageous from the point of vicw of fire-fighting actions. The considerable deflections are connected with a small thickness of the slabs in relation to their length and with their disability to operate as the reinforced concrete items. In the tests described in litcrature no sudden failure of pretensioned prestressed concrete items has been reported without the prior considerable deflections of these items.

If the calculation of fire resistance of a pretensioned prestressed concrete item for the required time of the fire exposure has been carried out by means of the same methods and criteria as for the reinforced concrete items ( such an advice might be found in some reports), the deflections of pretensioned prestressed concrete items shall be checked taking into consideration the drop of pretension force corresponding with the assumed time of fire exposure. This can be carried out by means of formulas or diagrams incorporated in this report. For example, in case of SP slabs the distance between the gravity centre of the prestressing strands from the SP slab bottom surface amounts to $4 \mathrm{~cm}(x=40 \mathrm{~mm})$. Let us indicate a value of $A$ and $B$ coefficients from Table 1:

$$
A=0.0101, B=-2.160
$$

In case of distances from the slab bottom surface different than in Table 1 , the interpolation method shall be applied. The percentage drop of pretension force within 60 minutes (fire resistance of the slabs evaluated by the comparative method) amounts to:

$$
\Delta P_{s}=0.0101 \cdot 60^{2}-2.160 \cdot 60=-93.24 \%
$$

Such a considerable drop of pretension force causes unacceptable excessive deflections appearing much more quickly than the loss of bearing capacity. Therefore, these slabs under fire conditions may perform worse than according to the defined fire resistance.

Taking into consideration the above - mentioned properties of the pretensioned prestressed concrete structures, an assumption of the criterion of excessive strains for the purpose of defining fire safety seems much more reasonable than a frequently applied criterion of the bearing capacity.

\section{Conclusions}

The issue of fire resistance of pretensioned prestressed concrete items is of a more complex character than that of the reinforced concrete items. Fading of the effects of stecl pretension takes place. This results in considerable strains of pretensioned prestressed concrete items, in appearance considerable opening of cracks, which leads to the failure of the item.

Figures 3 and 4 show the temperature distributions and corresponding curves of drop of pretension force described by the formula (3). This enables to define a percentage drop of pretension force in any time point of a standard fire or of an actual fire with a similar "temperature-time" distribution; it enables also defining a period of time after which a dangerous drop of pretension forces takes place in the structure.

A simplified way of defining the fire resistance might be based upon the indication of the drop of pretension force, dangerous from the point of view of excessive deflections, and then upon the indication of time, after which this phenomenon takes place, applying the diagrams, tables and formulas having been proposed in this report. 


\section{References}

1. M.G. Claudde: Association Scientifique de lat Précontrainte // Ann. T'B'TP séric: Beton Précontraint, No 12/1971.

2. T. Cahill, G. D. Branch: Long term relaxation behaviour of stabilized prestressing wires and strands, FIP 1979.

3. Z. Bednarek. Studium w'plywu nieustalonych warunków termicznyeh na stosowane pray ocenie bezpieczeństwa poizarowego konstrukcji parametry wytrzymakosciowe stali budowlanych. Monografia. Wyd. SGSP, Warszawa, 1992.

freiktit 19960410

\section{REI AKSACIJOS DIDEJJIMO NUO TEMPERATŪROS IS ANKSTO ITEMITOSE GELZZBETONINESE KONSTRUKCIJOSE TYRIMAS}

\section{Z.Bednarek}

\section{Santrauka}

Nagrinejamos lenkiamy̨ geľbetoninių elementy su iš anksto jitempta armatūra ugniai atsparumo jivertinimo problemos. Svarbiausias faktorius, nulemiantis tokiy konstrukciju elgseną gaisro metu, yra vadinamasis įtempimo jégos šuolis, kurị sukelia pagreitinta plieno armatūros i̊tempimy relaksacija aukštos temperatūros poveikio sąlygomis. Eksperimentais nustatyti ịtempimo jègos šuolio parametrai dviem serijoms vielinès armatūros vijų esant jvairicms apsauginiy sluoksnię storiams standartinio gaisro režimo sąlygomis. Pasiūlyta ịtempimy nuostolių dèl pagreitintos plieno temperatürines relaksacijos skaičiavimo formule.
Zoja BEDNAREK. Dr Eng., Assistant Professor. Deputy Head of Technical Science chair at the Main School of Fire Scrvice in Warsaw, 52/54 Slowackicgo St, 00-967 Warsaw, Poland.

In 1976 Dr Eng. degree in construction engineering. Since 1980 working as the head of Applied Mechanics department, since 1986 as Assistant professor and the deputy head of Technical Science chair. Research interests: safety and strength of building structures at high temperatures, fire safety and fire resistance of structural members, reinforcement of building structures, strength of steel and concrete under the conditions of fire. 